\title{
Spatial and Temporal Baseflow Filtering of River Nzoia in Nzoia Basin
}

\author{
Juma Shadrack Wegulo \\ Masinde Muliro University of Science \& Technology, P.O. Box -50100, Kakamega, Kenya \\ Professor Basilo O'ngor PhD (Civil Engineering) \\ Masinde Muliro University of Science and Technology, P.O. Box -50100, Kakamega, Kenya \\ Dr Caroline Kwamboka (PhD (Civil Engineering)) \\ Masinde Muliro University of Science and Technology P.O. Box -50100, Kakamega, Kenya \\ DOI: $10.31364 / \mathrm{SCIRJ} / \mathrm{v} 7.17 .2019 . \mathrm{P} 0719679$ \\ http://dx.doi.org/10.31364/SCIRJ/v7.i7.2019.P0719679
}

\begin{abstract}
In Nzoia River, water quality and quantity has been hypothesized to be deteriorating due to human activities in the recent past. Water quantity and quality are highly stressed because of the increase in water demand which is contributed to by the high growth in population, urbanization, food, and energy production. The purpose of this study was to determine the spatial and temporal variation of water quality and quantity as a result of Baseflow filtering using WETSPRO Tool. The study was guided by the following study objectives; To determine the water quality in the upper and lower sections of the river in Nzoia River; determine the flow/discharge rate in different sections of the river in Nzoia River; determine the WETSPRO calibration and validation in Nzoia River and to predict the quality and the quantity of the water in the upper and lower sections of Nzoia River. An experimental research design was adopted during the study. The target population consisted of water samples collected from three sample points in the Nzoia River. The sample size was made of two sample points where the two were selected after meeting the requirement of the dropping from the top of a waterfall in order to create the upstream and downstream. Water Engineering Time Series PROcessing tool (WETSPRO) was used in the analysis of the datasheet. The results revealed, the water quality of River Nzoia ranged from excellent to fair in the downstream direction attributed to increase in pollution levels as evidenced by high water turbidity, poor transparency, low species richness, composition and diversity of the benthic macro-invertebrate fauna. This was due to natural forces and increase in anthropogenic activities. On the discharge rate from different sections of River Nzoia, the study concluded that different sections of the river had different discharge rate. This is as a result of inflow or outflow of groundwater to or from the area, stream modifications such as irrigation diversions, as well as evaporation and evapotranspiration from the area's land and plant surfaces. On WETSPRO calibration and validation in Nzoia River the study concluded that the model was calibrated by adjusting $\mathrm{n}$ in the HD Model Parameters to reduce the inconsistency between measured and simulated values. The model was efficient at value of 0.75 , and RMSE of $0.05 \mathrm{~m} 3 \mathrm{~s}-1$.
\end{abstract}

Keywords: Baseflow, Filtering, Temporal, flow discharge, discharge rate, turbidity, stream modification.

\section{Introduction}

Knowledge about base flow is essential in assessing water quality, forecasting streamflow, allocating water supply, and designing hydropower plants under the low-flow conditions. Alteration in the quality and or quantity of water usually results in immediate changes in the structure and function of ecosystems. This may include the number and types of organisms that can survive in the altered environment. Water use trends and demand most often serve as a guide to the availability of water in terms of quantity and quality. Most often, an increase in demand for water and its use is directly proportional to the deterioration in its quality. However, the amount of waste discharge tends increase with rising water demand, although the relationship depends in detail on the amount of water and the specific use involved.

Nzoia River lies between latitudes $1^{\circ} 30^{\prime} \mathrm{N}$ and $0^{\circ} 05^{\prime} \mathrm{S}$ and longitudes $34^{\circ}$ and $35^{\circ} 45^{\prime} \mathrm{E}$. The Nzoia River originates from Cherangani Hills at a mean elevation of $2300 \mathrm{~m}$ above sea level (asl) and drains into Lake Victoria at an altitude of $1000 \mathrm{~m}$ asl. It runs approximately South-West and measures about $334 \mathrm{~km}$ with a catchment area of about 12,900 km2, with a mean annual discharge of 1777 x 106 m3/year. The population within the Basin is more than 3 million comprising of Bantu and Nilotes. 
Nzoia River is quite of importance as it contributes vastly to the shared waters of Lake Victoria. It lies within the South-Eastern part of Mt Elgon and the Western slopes of the Cherangani Hills. Many other rivers feed the Nzoia before it discharges into Lake Victoria. The major ones are Koitogos (Sabwani), Moiben, Little Nzoia, EwasoRongai, Kibisi, Kipkaren and Kuywa. Other tributaries are Chwele, Khalaba, Lusumu and Viratsi.

The Basin passes through Marakwet, Keiyo, West Pokot, Trans Nzoia, UasinGishu, and Nandi North in Rift Valley Province; Lugari, Mt. Elgon, Bungoma, Kakamega, Butere-Mumias, and Busia, districts in Western Province; and Siaya in Nyanza Province.

The climate of the Basin is mainly tropical humid characterized by day temperatures varying between $16^{\circ} \mathrm{C}$ in the highland areas of Cherangani and Mt. Elgon to $28^{\circ} \mathrm{C}$ in the lower semi-arid areas on annual basis. The mean annual night temperatures vary between $4^{\circ}$ $\mathrm{C}$ in the highland areas to $16^{\circ} \mathrm{C}$ in the semi-arid areas. Mean annual rainfall varies from a maximum of 1100 to $2700 \mathrm{~mm}$ and a minimum of 600 to $1100 \mathrm{~mm}$. The area experiences four seasons in a year as a result of the inter-tropical convergence zone (ITCZ). There are two rainy seasons and two dry seasons, namely, short rains (October to December) and the long rains (March to May). The dry seasons occur in the months of January to February and June to September. However the local relief and influences of the Lake Victoria modify the regular weather pattern. The economy of the region is still largely rural and more than $90 \%$ of the population earns its living from agriculture and livestock. The farms are privately owned and on average $1-3$ hectares. However, large commercial farms with an average of 50-100 hectares or more characterize such districts as Trans Nzoia and Uasin Gishu.

\section{Methodology}

\subsection{Research Methodology}

This study adopted an experimental research design. The research design was appropriate as it enabled the researcher manipulate one variable, and control/randomize the rest of the variables. The research design had a control group, the subjects were randomly assigned between the groups, and the researcher only tested one effect at a time. The experimental research helped the researcher sample the water quality parameters from the different sections of the River Nzoia.

\subsection{Materials and Methods}

\subsubsection{Materials}

The materials used to measure water quality in terms of potential of hydrogen $(\mathrm{pH})$, Temperature, dissolved Oxygen, Turbidity and Salinity are outlined below: pH Meter, Thermometer, Dissolved oxygen sensor, Formazin Turbidity Unit.

To measure Distribution Intensity and Frequency of water movement, the following materials were used: Frequency meters, Secchi disk

\subsubsection{Procedure}

1:50,000 Topographic Map Sheets (TMS) were used to delineate River Nzoia catchment, which falls under the small or medium size watersheds. A $25 \mathrm{~m}$ grid cell was derived from 1:50,000 topographical maps following a guideline by Maidment (ESRI, 1999). A Digital Elevation Model (DEM) was subsequently generated from TMS after scanning and digitization and catchment map finally delineated from DEM using Arc View GIS and subdivided according to land-use practice

Streamflow was analyzed using the Base Flow Index (BFI) hydrograph separation computer program to identify base-flow and surface-runoff components. To develop a hydrodynamic model for River Nzoia a MIKE 11 modeling system (DHI, 2004) was used. The river's catchment was delineated and subsequently subdivided according to land-use practice into (Lz) Forested zone (Fz), (middle) Agricultural zone (Az), (lower) Urban zone and (Uz) The rainfall runoff processes were simulated using the North America Mesoscale module (NAM). The NAM output discharge was filtered in its subflows using WETSPRO, and the hydrodynamic model was developed using MIKE $11 \mathrm{HD}$ module. Model calibration and validation was done on the basis of available observed river discharge data at $\mathrm{Fz}-\mathrm{Az} ; \mathrm{Az}-\mathrm{Uz}$ boundaries.

\subsubsection{Model Setup and Data Requirement}

This study was limited to three catchment storages area: surface storage (U), root zone storage (L), and groundwater storages (G). Model parameters were Coefficient of overland flow (CQOF) and Coefficient of interflow (CQIF), for overland flow and interflow runoff coefficients, respectively. Rainfall, evaporation and discharge data were simulated on daily basis for a period of 25 years. The model was the calibrated and validated using the observed discharge data at the catchment outlet. The reliability of the NAM was

WWW.scirj.org

(C) 2019, Scientific Research Journal

http://dx.doi.org/10.31364/SCIRJ/v7.i7.2019.P0719679 
evaluated based on the Efficiency Index (EI) as described by Nash and Sutcliffe (1970). The fully description of River Nzoia NAM model is available in "Rainfall Runoff Model for River Nzoia Catchment by Chibole (2011).

\section{Results}

The study sought to determine the water quality in the upper and lower sections of the Nzoia River. This was done by carrying out tests of the Morphological Characteristics, Physical and chemical characteristics of River Nzoia.

Table 4.1: Morphology and Water Quality in the Upper and Lower Sections of the Nzoia River

\begin{tabular}{|l|l|l|l|}
\hline \multirow{2}{*}{ Parameter } & Site 1 & Site 2 & Site 3 \\
\cline { 2 - 4 } & Upper & Middle & Lower \\
\hline Temperature $\left({ }^{\circ} \mathrm{C}\right)$ & $15.3 \pm 0.46$ & $17.9 \pm 0.67$ & $19.7 \pm 0.55$ \\
\hline pH & $7.7 \pm 0.07$ & $7.7 \pm 0.10$ & $7.2 \pm 1.16$ \\
\hline DO $(\mathrm{mgl})$ & $7.5 \pm 0.59$ & $6.9 \pm 0.54$ & $5.0 \pm 0.62$ \\
\hline Conductivity $(\mu \mathrm{Scm}-1)$ & $134.9 \pm 7.03$ & $157.0 \pm 10.76$ & $166.0 \pm 12.69$ \\
\hline TSS $(\mathrm{mgl}-1)$ & $13.1 \pm 1.86$ & $26.0 \pm 6.82$ & $44.8 \pm 8.62$ \\
\hline Turbidity $(\mathrm{NTUs})$ & $78.0 \pm 27.1$ & $112.0 \pm 40.9$ & $182 \pm 39.2$ \\
\hline Width $(\mathrm{m})$ & $4.1 \pm 0.33$ & $5.0 \pm 0.51$ & $4.1 \pm 0.72$ \\
\hline Transparency $(\mathrm{m})$ & $0.6 \pm 0.11$ & $0.6 \pm 0.11$ & $0.23 \pm 0.05$ \\
\hline Velocity $(\mathrm{m} / \mathrm{s}) 1.2 \pm 0.10$ & $12.0 \pm 0.10$ & $4.0 \pm 0.12$ & $15.0 \pm 1.15$ \\
\hline Depth $(\mathrm{m})$ & $0.9 \pm 0.04$ & $0.7 \pm 0.05$ & $1.5 \pm 1.15$ \\
\hline TDS $(\mathrm{mg} / \mathrm{l})$ & $257.8 \pm 21.7$ & $291.8 \pm 25.2$ & $348.0 \pm 22.9$ \\
\hline
\end{tabular}

\section{River Widths}

River widths of the site I were $4.1 \pm 0.33 \mathrm{~m}$; site II $5.0 \pm 0.51 \mathrm{~m}$; and site III $4.1 \pm 0.72$; during the entire sampling period at the forested (site I), agricultural and urban sites respectively. Mean river widths at the three sampling sites, however, did not vary significantly (Kruskall-Wallis H test, $\mathrm{K}=1.715, \mathrm{p}>0.05$ ). Two sites (site I and III) had equal mean widths for the entire sampling period of $4.1 \pm 0.33 \mathrm{~m}$ and $4.1 \pm 0.72 \mathrm{~m}$. Respectively while site II recorded the highest mean width of $5 \pm 0.51 \mathrm{~m}$. The rocky bottom riverbed at site II made water to spread out and hence, increased its width. River width at different sampling sites during sampling periods differed significantly. The river widths at site I had minimal variations that ranged from $2.26-7.15 \mathrm{~m}$.

\section{Water Depths}

There was a variation of water mean depths from a low of $0.9 \pm 0.04 \mathrm{~m} ., 0.7 \pm 0.05 \mathrm{~m}$. and $1.5 \pm 1.15 \mathrm{~m}$. at sites I, II, and III respectively. Mean water depth however, did not differ significantly at sampling sites Kruskall Wallis $\mathrm{H}$ test, $\mathrm{K}=1.24 ; \mathrm{p}<0.05$ ). However, expected results were that the depths of the river should have increased in the downstream direction as is always with other lotic bodies in other parts of the world

\section{Water Velocity}

Water velocity at the three sampling sites on River Nzoia did not differ significantly (Kruskall Wallis $\mathrm{H}$ test, $\mathrm{K}=4.820, \mathrm{P}>0.05$ ). Site II had the lowest water velocity averaging $4.0 \pm 0.12 \mathrm{~m} / \mathrm{s}$ compared sites I and III that mean velocities of $12.0 \pm 0.10 \mathrm{~m} / \mathrm{s}$ and 15.0 $\pm 1.15 \mathrm{~m} / \mathrm{s}$. All sampling sites were characterized by almost constant velocities during sampling period. Site II had the lowest water velocity averaging $4.0 \pm 0.12 \mathrm{~m} / \mathrm{s}$ compared with sites I and III had mean velocities of $12.0 \pm 0.10 \mathrm{~m} / \mathrm{s}$ and $15.0 \pm 1.15 \mathrm{~m} / \mathrm{s}$ respectively.

\section{Water Quality in the Upper and Lower Sections of the Nzoia River}

Table 4.2 shows the pertinent catchment characteristics of River Nzoia. 
Table 4.2: NAM model parameters after calibration

\begin{tabular}{lll}
\hline Parameter & Unit & Value \\
\hline Area of catchment & $\mathrm{Km}^{2}$ & 225 \\
Max water content surface zone & $\mathrm{Mm}$ & 20 \\
Max water content root zone & $\mathrm{Mm}$ & 200 \\
CQOF & Dimensionless & 0.3 \\
Time constant routing QIF & $\mathrm{Hr}$ & 700 \\
Time constant routing QOF & $\mathrm{Hr}$ & 20 \\
Root zone threshold value for QIF & dimensionless & 0.1 \\
\hline
\end{tabular}

\section{Conclusion}

The water quality of River Nzoia varied from excellent to fair in the downstream direction due to increase in pollution levels as evidenced by high water turbidity, poor transparency, low species richness, composition and diversity of the benthic macroinvertebrate fauna. This was as a result of natural forces and an increase in anthropogenic activities. The results obtained were precise and reliable and thus they can be applied as a point of reference in future bio-assessments in the region. The results can also be used to make decisions on water quality and ecological integrity of rivers in the region

The study concluded that different sections of the river had different discharge rate. This is attributed to inflow or outflow of groundwater to or from the area, stream modifications such as irrigation diversions, as well as evaporation and evapotranspiration from the area's land and plant surfaces. Lower parts of the river were able to transport more sediments as it had a high discharge rate compared to the other sections of the river

The study concluded that the WETSPRO model was calibrated by adjusting $n$ in the HD Model Parameters to reduce the discrepancy between measured and simulated values. The model was efficient at value of 0.75 , and RMSE of $0.05 \mathrm{~m}^{3} \mathrm{~s}^{-1}$.

The study concluded that quality and the quantity of the water in the upper and lower sections of Nzoia River, was determined by the human activities in the river's catchment which include the population, agricultural activities and settlement-built ups.

\section{Acknowledgement}

Special thanks to the experts who were involved in the validation survey for this research project, the provision of data: Lake Victoria Water Services Board (LVNWSB), Water Resources Authority (WRA) of the experts who participated/contributed. Without their passionate participation and input, the validation survey could not have been successfully conducted. Thank you

\section{References}

Brooks, K.N.; P.F. Ffolliott; H.M. Gregersen \& DeBano L.F. (2007). Hydrology and the management of watersheds. Second edition. Iowa State University Press, Ames, Iowa.

Brown, R. M., McLelland, N. I., Deininger, R. A. and Tozer, R. G. (2003). A Water Quality Index - Do we dare? Water and Sewage Works, October: 339-343

Bryne, J. and Dates, G. (1997). Living Waters, Using Benthic Macro-invertebrates and Habit to Assess Your Riverees Health. River Watch Network. Boca R।

Chapman, L. J., Schneider, K. R., Apodaca, C. and Chapman, C. A. (2004). Respiratory ecology of macro-invertebrates in a swamp river system of East Africa, Biotropica, 36: (4) 572- 585.

Chibole, O.K. (2011). Rainfall Runoff Model for River Sosiani’s Catchment 606: Proceedings of the SecondInternational Conference on Advances in Engineering and Technology. Entebbe, Uganda. 
Dallas, H. F. and Day, J. A. (1993). The effects of variables on riverine ecosystems; a review Water

Quality Research Commission. South African Journal of Aquatic Sciences 24: 9.

Hynes, H. B. N. (1972). The ecology of running waters. Liverpool: Liverpool Press.

Johnson, M. J., Giller, P. S. O־Halloran, J., O־Gorman and Gallager, M.B. (2005).A novel approach to assess the impact of land use activity on chemical and biological parameters $\quad$ in river catchments. Freshwater Biology, 50: 12732032.

Johnson, R. (2008). The forest cycle and low river flows: a review of UK and international studies. Forest Ecology and Management 109:1-7.

Weatherly, N. S. and Ormerod, S. J. (1990). Landscape scales influences on stream habitats and $\quad$ biota. Freshwater Biology, 6: 65 89. 